\title{
En híbrida mezcolanza: Exile and Cultural Anxiety in Alirio Díaz Guerra's Lucas Guevara
}

\section{Jeff Browitt, Institute for International Studies, University of Technology, Sydney}

In 1914, Lucas Guevara, a novel by the Colombian exile and writer, Alirio Díaz Guerra, was first published in New York. It remained forgotten until Nicolás Kanellos, the Director of the 'Recovering the U.S. Hispanic Literary Heritage Project', uncovered a copy of this first edition in a New York public library in 1976. The novel has since been claimed as the earliest about Latin American immigration to the United States written in Spanish. This fact alone merits its study. The novel is also unique in that typically it is literature by Puerto Ricans, Mexicans and Cubans, and not a Colombian, that is most associated with the Latin American migrant experience. The novel was published for a second time in 2001 by Arte Público Press in Houston, Texas. This second edition comes complete with a critical-biographical introduction by Kanellos and Imra Liz Hernández, which presents the novel as the precursor of a developing genre of a certain type of Latin American immigrant literature centred on the naïve migrant (el verde) who arrives in the United States inspired by the opportunities which the metropolis supposedly affords, but who nevertheless suffers a series of misfortunes because of the inability to adapt to or withstand the hostility of the new culture. The price to be paid for this failure to adapt is to return home, or to remain and die. ${ }^{1}$ Díaz Guerra portrays just such a hapless figure in Lucas Guevara. Though on the level of overt content the novel is a stereotypical denunciation of a supposedly amoral and corrupting US society, it is fascinating for the

1 Kanellos and Hernández list several other novels among which Lucas Guevara seems to be the first: Conrado Espinosa, El sol de Texas (1927); Daniel Venegas, Las aventuras de Don Chipote (1928); Gustavo de Alemán Bolaños, La factoría (1925), Guillermo Cotto-Thorner, Trópico de Manhattan (1951); René Marqués, La carreta (1952); Iván Acosta, El súper (1977); Mario Bencastro, Odisea del Norte (1998);

Roberto Quesada, The Big Banana (1998) and Nunca entres por Miami (2002).

Portal Journal of Multidisciplinary International Studies Vol. 2, No. 1 January 2005

ISSN: 1449-2490

http://epress.lib.uts.edu.au/journals/portal/splash/ 
insight it provides, through the narrative voice and the authorial presence, of the anxieties secular modernity occasioned for a certain kind of exilic subjectivity (masculine, Spanish American, elite) still under the sway of a conservative, Catholic morality.

Alirio Díaz Guerra was born in Colombia in 1862 into a prominent family of politicians, his father being the federal treasurer for the Liberal Party government at one stage. He was educated at the Universidad Nacional de Colombia en Bogotá, firstly in letters and then in medicine. He began to write and publish poetry at an early age. Like other Hispanic letrados, ${ }^{2}$ Díaz Guerra early on showed a dual liking for poetry and politics. In 1884, when he was barely 22, he founded a newspaper, El Liberal, in opposition to the then conservative Colombian administration. Shortly after the Liberals rose up in armed revolt against the proposed constitutional changes by the ruling Conservative Party. The Liberals were defeated and in 1885 Díaz Guerra was obliged to flee, penniless, to Venezuela where he would spend the next ten years. Because of his social and political standing in Colombia and because of a Liberal-minded government in power in Venezuela, he was soon able to secure employment, firstly as Surgeon General of the Central Railroad, subsequently as private secretary to the then Venezuelan president, Joaquín Crespo. When Crespo was deposed by the political opposition, he was still able to secure employment as Director of Public Education. When Crespo returned for a second term, he was appointed Secretary of State. He married the daughter of a well-todo family and in between work and family duties, continued to publish poetry, but also, and importantly, inflammatory articles against the conservative Colombian government of the day.

In 1895, Díaz Guerra wrote a series of secret letters on government letterhead inciting a Liberal revolution against the then Colombian government. The letters, which also implicated Crespo in the 'Colombian revolutionary cause', were handed over by a traitorous co-conspirator to a Panamanian newspaper for publication. Due to the acute

2 A letrado was a patrician intellectual with a cosmopolitan and universalizing worldview whose credentials were based on the social authority of the scribal culture of 'letters', which straddled law, literature, politics and history, and which was crucially linked to nationalism and state-building in nineteenth-century Latin America. 
embarrassment this occasioned the Venezuelan government and in order to avoid a major diplomatic incident, Díaz Guerra was forced to go into exile (Díaz Guerra 1933, 223-36). The alternative was to remain and probably face a firing squad. He sailed to New York in 1895, the same year that José Martí, at the time perhaps the most prominent of Latin American political exiles, left to fight (and soon die) against the Spanish colonial government in Cuba. Little is known of Díaz Guerra’s early years in New York except that he was director of the General Office of the Republic of Colombia for three years not long after his arrival and that he travelled extensively in Europe before returning to the United States to take up employment as an international sales representative for Sharp and Dohme, a pharmaceutical company. Somewhere during this period he also made the transition from exile to confirmed immigrant. Except for international travels for Sharp \& Dohme, including occasional visits to Latin America, Díaz Guerra spent the rest of his life in New York until sometime in the late 1930s when he died, though exact details are unknown. During his time in New York he was a foreign correspondent for several Latin American newspapers and published a few more volumes of poetry and a couple of novels. Only one novel has survived, Lucas Guevara, which was published after he had been in the city for almost 20 years.

Not long before he died and at the instigation of Venezuelan friends, Díaz Guerra wrote a memoir of his life in Venezuela (Diez años en Venezuela, 1933), which, though postdating Lucas Guevara, was written in an almost archaic, florid, romantic style. In the very opening chapter relating his ignoble flight from Colombia to Caracas in a French steamboat, Díaz Guerra uncannily echoes the plot of his novel 20 years earlier and its denouement in the suicide of its main character, Lucas Guevara. He recalls his depressed state at the time of his forced exile:

Only someone born, brought up and educated in a social sphere of comfort and decency ... is capable of understanding how humanity can be reduced to the category of a beast without, by beneficent providence, either losing his mind or resorting to the solution of the desperate - suicide (Díaz Guerra 1933, 10, my translation).

Shortly after his arrival in Venezuela, Díaz Guerra was immediately invited into the circles of high-print culture as a member of the Venezuelan Academy of Language and 
by having his poems published in the most popular daily newspaper. His literary success was due to his ability to craft verse in the ornate style of Spanish and Latin American romanticism, singing the praises of the great men and deeds of the Venezuelan republic or writing hymns about chaste virgins and religious devotion: 'Christian faith/you are the blessed one/the magical flower of paternal dwelling/which in the rough squalls of life/conserves its verdure and fragrance' (54, my translation). But literary success was no doubt also due to the social and political capital which elite credentials afforded, a capital which was transferable across national boundaries in Spanish America. Díaz Guerra was therefore soon able to ingratiate himself with the Liberal Venzuelan power elite, which ensured a succession of government postings. The Venezuelan memoirs have only minor historical interest, but for the purposes of this reading of his novel what is important to note is the way Díaz Guerra carefully constructs his own persona: Christian, virtuous, maritally faithful, noble, loyal, altruistic, nationalistic, and so forth. These values embedded in his literary and autobiographical writings provide the prism through which he would subsequently come to judge the supposed failings of society and culture in New York as portrayed in his novel.

The novel follows the trajectory of a young man (Lucas Guevara) from a middle-class family who arrives in New York from Santa Catalina, a rural town in a South or Central American country. He has a stipend to support him while he studies, the idea being that he will return with some sort of technological training that will be put to good use in his own country at some future date. The specific country is never named, but there are clues to suggest it is Colombia, though this has no real bearing on the structure of the novel or its interpretation. The novel's theme is common to nineteenth-century bildungsroman in which a young man sets out for the big city in search of success and fulfilment, but only finds disillusion. There is, however, no self-development or overcoming of obstacles, no final triumph. Through the novel we get a feel for the texture of daily experience in New York in the first decade of the twentieth century and the cultural consequences of modern capitalism: the metropolis's feverish tempo and anonymous encounters, the play of desires unleashed by consumerism and secularism, the exploitation of the newly-arrived immigrants, the Bowery as representative of the human detritus of capitalist modernity, 
and a skyline dominated by the wonders of modern technology, including the Brooklyn Bridge and the aerial railways, and that symbol of promise, The Statue of Liberty.

Soon after his arrival, Lucas is met by Jacinto Peñuela, a street-wise New York Latino pícaro, who seems to specialize in preying on the ingenuous. Peñuela is not so much a swindler as a sponger who attaches himself as guide and counsellor to greenhorns, shows them around the city and gets them to pay for everything. Peñuela takes Lucas to meet the New York businessmen from Lucas's home country to whom Lucas must present his letters of introduction, the businessmen agreeing to monitor Lucas's progress as well as his monthly allowance. Peñuela also directs Lucas to a boarding house, to the chagrin of Guevara’s businessmen compatriots, equally versed in exploiting the naïve. These businessmen, like Peñuela, make money on the side directing novitiates like Guevara to stores, bars, and boarding houses from which a kickback is to be gained. There is a very real sociological background to this story since at least forty percent of New York's inhabitants were immigrants during the period of the novel and boarding houses and tenement slums were the principal housing options available.

Peñuela gradually introduces Lucas to New York life around the Lower East Side, famously the home to many a generation of immigrants, where he is quickly enthused by New York’s women, especially the 'siren temptresses of the Bowery’ (29, my translation). He is soon having affairs with the women at the boarding house, frequenting bars and visiting prostitutes and generally dissipating his energies in nights of debauchery. New York, or more particularly in the novel, the Lower East Side, thus becomes a moral landscape against which Lucas's misfortunes are played out. He has a run-in with his first boarding-house proprietor and has to move to another lodging. He has a brief and disastrous (forced) marriage, manages to spend his monthly stipend too quickly, has a falling out with his father's acquaintances because of his irresponsible behaviour, is briefly jailed for hurling a vase in the face of one of them in a fit if rage, and is bailed out by a widow who, finding him attractive, invites him to live with her as a kept man. When his stipend is suspended, he soon begins to take on a role similar to Peñuela, preying on newly arrived Latin American immigrants and visitors keen to know the 
Lower East Side. He is eventually thrown out by the widow and progressively slides into poverty and depression, living the life of the most destitute and homeless in the big metropolis, falling victim to all kinds of abuse and exploitation. He works a summer on Coney Island, but is once again on the street when the vacation season finishes. At the end, broke and disillusioned, he commits suicide by throwing himself of the Brooklyn Bridge. Though he is the main protagonist whose tragic suicide is supposed to command our attention as readers, by the end of the novel his self-indulgent behaviour leaves the reader feeling unsympathetic. Whatever the shortcomings of the novel on the level of content, it seems to want to function as a condensed allegory of the indignities and lost dreams suffered by Latin Americans who arrive in the United States, principally men who feel themselves symbolically emasculated in what is portrayed as a hostile, godless, exploitative and racist Anglo-American culture. Nevertheless, there are limits to this allegorical dimension, most notably in terms of the class position of both the narrative voice and the protagonist. I will return to this issue in the conclusion.

In their critical introduction, Kanellos and Hernández point out how Lucas Guevara is not only the earliest known novel of immigration written in Spanish, but also that it is the precursor in 'structure and formula' of many novels to follow throughout the twentieth century, both in Spanish and English, which deal with a similar theme: the disingenuous Latin American immigrant, el verde (greenhorn), victim of all kinds of abuse in the United States, including at the hands of Anglo-American women, who personify the avarice and treachery of Anglo-Saxon culture and civilization. In the process, such novels establish a counter-myth in Spanish, which is:

[...] the opposite of the American Dream ... the opposite of what occurs in the novel of immigration in English, which upholds that dream as the essence of the American bildungsroman, whose most clear examples are The American by Howard Fast, Studs Lonigan by James Farell, America, America by Elia Kazan and Call It Sleep by Henry Roth. In fact Hispanics themselves who write their ethnic autobiographies in English scrupulously follow this bildungsroman of the American Dream: Oscar Hijuelos, Edward Rivera, Esmeralda Santiago, Víctor Villaseñor, etc. (Kanellos \& Hernández 2001, iv-v, my translation).

Nevertheless, Kanellos and Hernández highlight both the simplistic binary on which Lucas Guevara is based - 'New York is Babylon while Santa Catalina is an Eden; New 
York is the seat of corruption and Santa Catalina, though poor and backward, is the realm of purity and innocence' - and the novel's 'misogynist vision of US women' (vii; x, my translation) devouring incautious immigrant men. Metropolitan culture and its materialism and licentiousness are thus strongly contrasted with the supposed more authentic and more worthy spiritual and cultural values embodied in the immigrant's own 'Hispanic' nation. ${ }^{3}$ Hence the moral to be drawn from such tales for Latin American readers is that it is better that 'they should remain at home and not allow themselves to be deceived by the myth of the United States, because the Metropolis, instead of being the path to perfection, is the path to destruction' (xv, my translation).

Kanellos and Hérnandez's critical introduction to the second edition of Lucas Guevara performs a valuable service in rescuing the book from oblivion and provides a highly commendable commentary. Yet it fails to sufficiently separate out the narrative voice from an analysis of the overt content (the storyline), missing an opportunity to engage with the contradictory tensions in the moral centre and filter through which this overt content is framed, interpreted and ideologised. Lucas Guevara may very well be received by the average or 'non-intellectual' reader on the level of manifest content - the ideological ‘message’ Kanellos and Hernández wish to extract about the rejection of Anglo-American culture and the preservation of authentic or higher, Hispanic moral values - but there is also a much deeper conflict at work in the stance of the narrative voice and by implication the implied author: the attempt to maintain a stable Latino masculinity in face of the secularising and emasculating metropolis. For instance, though Kanellos and Hernández call attention to the blatant misogyny of the novel, they do not investigate what is clearly an unconscious and ambivalent attitude on the part of the narrative voice towards sexuality nor the class and racial anxieties unleashed by social mixing in the modern metropolis.

3 Here the word 'Hispanic' is used ironically to signal the controversy over its use vis-à-vis the more aceptable (though still problematic) 'Latino'. Hispanic 'spiritual and cultural values', certainly those foregrounded in the narrative voice in the novel, could be said to be those derived from an idealised, upper-class version of the legacy of Iberian colonialism and its social, cultural and religious overlay on those societies now deemed 'Latin American'. 
Though Lucas Guevara is a lachrymose, stereotypical and conventional denunciation of the supposed evils of an amoral US society and the libertine and materialistic values underpinning it, a closer reading of the novel leads away from a concentration on the main character and the storyline or récit: the least interesting personage in the novel is Lucas Guevara himself. As opposed to most other Latino immigrants from the underclasses doing it tough on the Lower East Side, Guevara lives off a stipend and has a semi-comfortable existence to return to if he so chooses. He is far removed from the fate of those hundreds of thousands of poverty-stricken immigrants and exile who were flooding into New York at the same time. Nor does he arouse our sympathy because of his self-indulgence and inability to learn from bitter experience: he seems constitutionally incapable of resisting problematic relationships with women, though he seems perfectly capable of absorbing other lessons of survival in the slums imparted by the street-wise Peñuela; in short, he is too much of a cardboard figure to be believable. At the end of the novel the reader herself would be quite justified in pushing him off the Brooklyn Bridge. Therefore, though the novel can no doubt be read as a cautionary tale of moral ruination within the context of its underlying Christian allegory, there is a certain kind of farcical quality to the story.

On a much deeper level, however, a picture emerges of Díaz Guerra himself as once a displaced, disenchanted intellectual exile who suffers an acute cultural and class anxiety in the transition from a patrician Arcadia to the secular, metropolitan culture of New York - the heart of capitalist, industrial modernity; thus his recognisably ambivalent experience of exile/immigration. The almost obsessive concentration on sexual activity and temptation highlight this dissonance and Díaz Guerra's own hesitant positioning visà-vis the United States and Colombia. Through a reading of the narrative voice, and by extension the implied author, and by juxtaposing the public persona carefully crafted through Díaz Guerra's memoirs of his ten-year sojourn in Venezuela, we witness his difficult coming to terms with a highly-charged New York society (in comparison to his homeland), not only because of the problems of an exile attempting to insert himself in a new society at the level to which he is accustomed (educated, middle-class, morally pious), but also the influences of sexual liberation brought on by secular modernity and 
the close proximity of volatile, eroticised bodies on the over-crowded Lower East Side of New York, the scene of the novel and Díaz Guerra’s point of entry into the United States.

It is significant, for example, that the attacks on US society are carried out by the narrative voice and not the voice of the protagonist. The narrator gives a survey of the Lower East Side from the point of view of a detached, cultured, middle-class, Latin American male. Because this narrative voice is an ostensibly 'reliable' voice of authority and omniscience and because there is no countervailing discourse to overtly contradict or undermine its perspective, we can fairly assume that certain elements in the narrative perspective are consonant with that of the implied author. This implied authorial presence in the narration expresses a kind of 'surplus', an excess which appears to escape conscious, authorial control, unaware of its own Freudian investments in the story. Such a discordant surplus centres on three recognizable thematic anxieties, of which the narrator/implied author seems only partially aware: firstly, an obsessive concern with female bodies, sexual promiscuity and uncontrollable desires (primarily blamed on stereotypical, libertine Anglo-American women); secondly, an acute class, racial and cultural anxiety in relation to the social and cultural mixing in the secular, rapidly modernizing metropolis; and thirdly, an ambivalent appreciation of technological modernity. It is through narrative commentary and focalisation that a picture emerges of a writer who initially lived a difficult relationship to New York, the tensions and negotiations of which cannot simply be banished at the end by a romanticized scene of suicide. This dissonance in the narrative perspective paradoxically makes Lucas Guevara an open text, in spite of its stereotypical plot.

How, then, is narrative perspective fashioned in the novel? The narrator establishes himself very early on as cultured via references to high European culture, as when, for instance, he names the operas from which the street musicians in the neighbourhood form their repertoire: 'wandering musicians who, with the greatest audacity, destroy fragments of opera and attack, in particular, Trovador, Traviata, Rigoletto y La Fille de Madame Angot' (Díaz Guerra 2001, 35, my translation). So too his reference to Guevara’s wife's letters of emotional outpouring, 'more eloquent, moving and passionate than all the 
epistles of Lord Chesterfield to his son' (63, my translation). These and similar nods to music and literature create an image of the cultured, ideal reader Díaz Guerra may have had in mind, and sets the novel apart from the more desperate tales of those who did not arrive in the United States with a stipend and had to endure untold hardships from the first moment. The dense use of figurative language also distances the narrator's voice from the main character and makes implied links with the knowing reader, since such elegant prose style is not the language of Lucas Guevara or the common, immigrant man in the street. Who, then, is the ideal reader? Most likely fellow middle- or upper-middleclass, cultured and morally pious Latin Americans, either in New York or would-be immigrants at home, who have taken their distance from both their compatriots and the host culture.

Another key characteristic of the narrative perspective is the repeated concern, expressed with irony and parodic humour, with sexuality and temptation and from a decidedly male perspective. Early on we have a characteristic, ironic aside when the narrator describes the belongings that Guevara packs for his trip to the United States, including 'few clothes, but abundant scapularies, rosaries and other pious odds and ends, articles which ... save souls from the temptations of Satan' (7, my translation). This seems none other than a mocking reference to what is to come - the precise inability of the protagonist to avoid such temptations. When Jacinto Peñuela takes Guevara to a sleazy cabaret, the narrator describes a scene in which 'around hundreds of small tables, men and women of all age and condition gathered in crude and licentious mix, repugnant even to the least observant gaze' (73, my translation). The narrator then goes on to describe the women as made up with lipstick, 'from the languidly pallid to the most intense; bare backs, lewd and heaving breasts, naked arms' (73, my translation); and focalises through the consciousness of Guevara, who ‘couldn’t understand how those female heads, sporting hats adorned with flowers and feathers, those busts covered with ribbons and lace, those waists wrapped in velvet and silk, could be bought with money and at cheap prices' (75, my translation). This is not exactly fictional verisimilitude, especially given the description of the bar that precedes this meditation and given that the sons of well-to-do estate owners and other ruling-class males in Latin America have historically had a 
reputation for availing themselves of prostitutes. Furthermore, the description of the bar and the females is eroticised by the narrator, not Guevara, which leads the reader to conjecture about the implied author's own proclivities for the well-contoured female body in the metropolis. This impression of the implied author's own erotic investments in the novel is reinforced by the narrator's descriptions of the rituals and financial transactions of prostitution in the cabarets and small hotels (72-8) as well of the interior and the workers of a brothel (97-104), the minute details of which seems nothing short of a knowledge born of experience. Such knowledge may derive from the author himself having frequented the bars and bordellos of the Lower East Side, or perhaps it derives from Díaz Guerra having possibly worked as an unregistered immigrant physician in such an industry, though there is no evidence to support the latter claim.

In a comic spoof, the narrator ridicules Don Emeterio, a businessman from the republic of ' $\mathrm{X}$ ' who is on a visit to New York. By this stage Lucas Guevara has adopted Jacinto Peñuela's style: preying on naïve paisanos who have just arrived from the homeland. Acccording to the narrator, Don Emeterio is apparently incapable of 'committing a marital infidelity' and desires to 'return without delay to his consort's side, whose absence was tearing apart his soul, ruining his appetite and depriving him of sleep’ (206, my translation). The reader immediately senses a set-up:

Hearing him speak in such terms of his domestic bliss and the way in which he dutifully complied with his maritial vows, Lucas was comforted by the thought that ... there still existed people who resisted the daily provocations of sin and that they are, for this reason, the bulwarks of society (2067, my translation).

Nevertheless, and in spite of telling Lucas that 'the day we separated, she placed around my neck the scapulary that I now wear ... and that is why I never commit indiscrections' (208, my translation), Don Emeterio gives in to temptation when Lucas offers him the chance to 'study and observe' the young women of New York:

'Well, that wouldn't be so bad, if I could,' replied Don Emeterio, 'because in all sincerity it would give me great pleasure to have the opportunity to see close up those places where they say chastity is commericalised; and I'd like to see them because ... a man should get to know everything, even the dens of vice, in order to better appreciate virtue. There are people who perhaps go to those places with base desires; others, like me, go to study’. 
'Well then, whenever you're ready, let’s go to school', replied Lucas (209, my translation).

Though these two passages are satirical, more importantly they show the narrative voice obviously delighting in the tale, neither denunciatory nor moralistic here, but rather hilarious, which leads one to surmise, along with other clues throughout the novel, that the style of a lot of the book is highly comic irony, rather than just a moralistic denunciation of the sins of the flesh.

In Chapter 32, the reader is given a detailed description so detailed of the interior and the functioning of a brothel: 'The investigative eye of the visitor is not satisfied with the simple panorama of the salon and wants to always discover the mysteries and intimacies hidden by the thick, damask curtains that shield the entrance to the contiguous room' (214, my translation). Really? The reader gets to enter the brothel, not through the focalization of Lucas Guevara or Don Emeterio, but that of the narrator, in spite of the reference to the 'investigator’. This description occurs before Lucas takes Don Emeterio to the brothel; in other words, it is not projected through the consciousness of one of the protagonists. A little further on, Díaz Guerra has one of the characters ironically declare: 'now is when one can appreciate the treasure of Christian morality that we possess in our homeland' (214, my translation). Rather than a simplistic moral denunciation, we are witness to an ambivalent staging of voyeuristic pleasure.

In yet another scene, the narrator mocks a pair of self-important Latin American financiers. Peñuela, feeling sorry for Lucas, who by this stage is penniless and in gaol for assault, goes to ask a couple of business acquaintances and friends of Lucas's family if they would help out. The visit becomes an occasion to send up the pompous Christian morality of the bankers as they hold forth on family values. Remember, we are reminded by the narrator, and Kanellos and Hernández in the introduction, that counterpoised to the licentiousness of US culture are more traditional, conservative 'Hispanic' values embodied in the native language and culture, in the Hispanic family, in the Catholic religion, in female chastity, and so forth: 
Don Nicomedes, with the characteristic eloquence his admirers claim he possesses, expounded his theories of marriage and ended by advising Peñuela to try and establish a home, for this is the foundation of morality, the source of love and peace and a positive base for the economy. Don Patrocinio couldn't avoid adding his five cents worth to his companion's luminous and civilizing exposition, limited, fortunately, to the passionate advice that in case he should have a family, that he not allow his children, least of all his daughters, read novels, for there exists no book of that nature that does not contain love affairs, which would be the equivalent of exposing virgin imaginations to the serpent of lust (170, my translation).

This is Díaz Guerra at his ironic and self-mocking best, not only sending up the stuffy and sham moralizing, but also gesturing tongue in cheek to his own novel, replete with sexual activity. Nor is the narrator averse to indulging in a bit of ribald masculine fantasy and stereotyping when he describes how female boarding house owners are attracted to Latin men: 'certain skins toasted by the sun of the tropics, certain black and somnolent eyes and certain anatomical traits, not common in the races of the North, generally impress the Eves with alabaster skin, blue eyes and blonde hair; probably a question of contrast’ (196, my translation).

Much of this satirical humour in Lucas Guevara is consonant with the picaresque style in Spanish literature. It is significant that Díaz Guerra uses many of the tropes of the picaresque form, including the naïve life story, the initiation of the protagonist into the corrupt underworld of vice, a genuine picaresque character in the person of Peñuela, social satire aimed at the deceitfulness and hypocrisy of a variety of class representatives of the pious and the powerful who prey on the most vulnerable, and so forth. Díaz Guerra also displays a genuine talent for caricature and satire underpinned by a moral vision, a hallmark of the best picaresque novelists. But so too does the novel diverge significantly from the picaresque form: it does not present the life story of a low-born central character who manages to climb the social ladder, who is transformed through self-knowledge; that is, there is no happy ending. Furthermore, the protagonist is not morally indifferent, but rather US society is portrayed as such. Indeed it is the protagonist who is portrayed as victim of deceitful women, and not the reverse, as in Zorilla's Don Juan Tenorio, ${ }^{4}$ echoes of which abound in the novel. In fact the novel in many ways is more Dickensian than anything else, in its contrast between the bourgeois gentility of the narrative perspective

4 Zorilla, José. (1844) Don Juan Tenorio. 
and the portrayal of the daily grind of lower-class survival, in its portrayal of the hypocrisy and corruption of a society dominated by utilitarian industrialism, by materialistic values, in its contrast between moral pretensions and actual behaviour. But more importantly for the purposes of this essay, what is obviously under threat throughout the novel, and by extension in the authorial stance, is a hitherto seemingly stable, Latino male subjectivity, now made vulnerable by an unfamiliar cultural and moral environment - the secular, modernising metropolis and its devouring women and its technology, symbolised respectively by two key landmarks: the Statue of Liberty ('Libertinism'); and the Brooklyn Bridge (technological progress).

This hitherto stable, Creole elite sense of self is also threatened by a loss of legislative hegemony by the developing massification of society. Chapter 37, for instance, is a set piece: a mini-chronicle of Coney Island, a descriptive break in the narrative progression similar to the meditation on the Brooklyn Bridge, the Bowery, boarding houses, New York reporters, and so forth. Like Martí's Coney Island crónica, it is an ambivalent portrait of the incipient culture industries and the massification and democratisation of 'bad taste', as well as social and cultural mixing. One scene in particular is significant for the narrative focus on the 'brazen' bodies at play on the beach:

In Coney Island ... there is an agitated abandon and fearful competition, forming an indescribable labyrinth, a heterogeneous group, a drawing without profile, a figure without contour, a formless agglomeration that injures the senses, delights, tires, makes one dizzy, annoyed and crazy ... [on the beach] the bathers, that is to say, the thousands of Adams and Eves of all classes and standings, romp for hours in the waves or writhe and rollick even more daringly on the sand, with a shamelessness capable of offending even the most trivial precepts of chastity, with their wet shirts stuck to their bodies and their naked arms and calves ... showing off provocative shapes (262, my translation).

This is publically-licensed sensuality, a phenomenon of the late nineteenth and early twentieth century in New York, which, along with cabaret culture, provided an avenue of release for an urban culture in rapid transformation, a 'new consumption, entertainment, sexuality', which, for Lewis Erenberg, culminates in the 1920s. This transformation was particularly vexing for cultural conservatives, who saw only 'cultural decline and urban 
pathology. The anonymity of city life, in their estimation, produced cultural decay' (Erenberg 1981, xiv). ${ }^{5}$

In Lucas Guevara, such metropolitan urbanisation and massification provoke a culturalnationalist rejection of Anglo-Saxons. There are constant references to the raza [española], which are cultural and moral, rather than biological, seeking to reinforce a perceived hierarchy of values and identity centred on the purported moral superiority of Hispanismo. From early on in the narrative, the panorama that greets the immigrant in New York is described as a 'seething mass of people of all races and all customs' (Díaz Guerra, 9, my translation). New York's population is variously described throughout the novel as the 'multitudes', 'the swarming crowd', 'a human wave', 'the whirlwind', and so forth. The anxiety at losing one's individuality within the crowd is expressed in a striking description of New York, in which Díaz Guerra unwittingly presages José Eustasio Rivera’s renowned 1928 novel, La vorágine (The Vortex), where the incautious and adventurous male is overwhelmed and ultimately destroyed by the Colombian jungle. Here, it is the burgeoning metropolis that threatens masculine individuality:

the future opened its maw and threatened to devour him ... he found himself in the entrails of New York, the frightful vortex that envelops everything, where the value of individuals is measured by the amount of money in their pockets; where nobody knows anybody; where the beggar is pursued with more vigour than the criminal; where every job, no matter how insignificant, has thousands of candidates who struggle and submit themselves to all kinds of indignity in order to win it ... where crammed into unhealthy buildings, succumb hundreds of people disinherited by luck, hungry and cold in the winter, starving and asphyxiated in summer. Thus he regarded New York, that immense, heterogeneous and hybrid mass, seat of all cultures, support of all customs, centre of all vices, ocean of all passions, market of honour, barrel in which all ambitions are amassed, desert in which all souls are sterilized and with the heat of mercantile fever, all hearts are petrified (143, my translation).

The anxieties of both the protagonist and the narrator in the face of modern life are remarkably similar to Georg Simmel's attempts to come to terms with modern urban life in his classic essay, 'The Metropolis and Mental Life', written at the turn of the nineteenth century (1903). Simmel stresses the overwhelming impact the modern

5 'From the late nineteenth century through World War I, men of all racial and class backgrounds found a lively round of entertainments and cheap amusements in the Bowery, Tenderloin, and Coney Island. In the 1850s, the vice and amusement center readied in the Bowery in lower New York, but by the 1870s and 1880s, it followed the mass of population northward to the Tenderloin ... and eastward to Coney Island in Brooklyn' (Erenberg 1981, 21); 'By 1900 Coney Island lured urban males in search of 'moist-lipped, slender girls' to its free and easy saloons and dancehalls' (22). 
metropolis and its ethos, proscribed by the money economy, has on the individual. The metropolis, as the 'locale of freedom' and the 'seat of cosmopolitanism', offers the possibility of anonymity and independence in comparison to the tightly-knit, conformist pressures of the small town; but it also takes the form of an indifferent and unresponsive juggernaut ruled by the logic of exchange value:

Money, with all its colorlessness and its indifferent quality, can become a common denominator of all values, it becomes the frightful leveller - irreparably it hollows out the core of things, their peculiarities, their specific values and their uniqueness and incomparability in a way which is beyond repair (Simmel 2002, 14).

For Simmel, then, the metropolis becomes the theatre of a struggle between the individual and overwhelming social and technological forces:

Here in buildings and in educational institutions, in the wonders and comforts of space-conquering technique, in the formations of social life and in the concrete institutions of the State is to be found such a tremendous richness of crystallizing, de-personalized cultural accomplishments that the personality can, so to speak, scarcely maintain itself in the face of it (19).

When Guevara is gaoled for assault, the prison cell comes to represent the Lower East Side in concentrated microcosm: 'in hybrid mix [en híbrida mezcolanza], irregardless of sex or class, are gathered beings whose misfortune, desperation, hunger and vice have torn them from the bosom of society’ (Díaz Guerra 2001, 159, my translation). This trope of negative cultural mixing is also utilised to frame Anglo-American women. Chapter 36, for example, is an extraordinary diatribe against the women of New York, a negative and sexist description of incipient women's liberation: 'the mixture of races, religion, tastes, aspirations, necessities and even languages has made of this woman a disaster' (252, my translation).

Whereas references to the raza in Lucas Guevara are clearly cultural and refer to all Latin Americans, the novel is nevertheless noteworthy for its overt racism against Jews and Chinese, which shades into cultural anxiety, especially faced with the social and cultural mixing for which New York has always been famous. The narrator attacks racism in the US press against individuals of the raza española (150), but is not averse to perpetuating racial stereotypes himself, as is witness the following passage: 
In Lucas's cell, a Chinese laundry owner was held for two or three days. He was accused of seducing a ten-year old girl, a practice to which are particularly addicted the sons of the Celestial Empire who, in spite of their apparent submissive, quiet and respectful temperament, all harbour the most artful tricks for doing away with the innocence of young girls barely out of the cradle, without the police being able, no matter what the effort, to effectively combat such appetites and customs of these sectarians of Confucious (162-3, my translation).

As if this were not enough, the man is described as emitting 'a few guttural sounds, like the barking of a dog with a cold' (164, my translation). In another context, the description could have been quite humorous, but after the accusations about child molestation, it reinforces the negative and racist stereotype. Given that the ideal reader for a novel written in Spanish was no doubt other Latin Americans, one can only confirm a general attitude in those days by the majority of ethnicities, including Latinos, towards the Chinese of the Lower East Side.

It is easy enough here to draw the obvious conclusion that the narrative point of view is class-conscious, racist and bigoted against non-Latin Americans. But in counterpoint to his criticisms of racism in the New York press, the opportunism of US newspaper reporters (151-7), the atrocious New York slums, especially the Bowery (28-35), New York women (250-6), mass culture in the form of the Coney Island amusement park (257-63) and so forth, the narrator also ridicules what he considers the pomposity and backwardness of a parade of Spanish American character types to be found around Lower Manhattan, whether it is through the rantings of the bombastic Don Cesareo holding forth about 'the shameful spectacle of yet another fraticidal war', which explains why 'the great nations, driven by a charitable and civilizing spirit, want to conquer us!' (146, my translation), or the criticisms of the Don Juanesque pretensions of Latin American male immigrants who think that it is

a rare woman who can resist their amorous advances once they look into their eyes, though not because they are seduced by youth in bloom, but because they can't help being fascinated by the way they converse by shouting in a strange language, and because each word is accompanied by all manner of gestures in a tireless gymnastics of hands, arms, legs and feet (222, my translation).

This is a most revealing comment: the narrator has adopted one of the formal prejudices of Anglo-Saxon culture vis-à-vis Latinos: ‘they’ speak in agitated discourse animating 
their speech with exaggerated bodily movements (still 'too close' to Nature). A partial distance is established with respect to the cultural traits and mannerisms of the narrator's own culture (perhaps unconsciously signalling Díaz Guerra’s own acculturation in the transition from exile to settled immigrant).

The Latin American dignitaries who flock to the grand hotels of New York in search of some sort of change in their personal circumstance, especially the 'rich fatcats' who provide a 'discordant and comic note' to the hotel scene, are also subjected to merciless description:

having the financial resources necessary to pay the elevated prices, they think they have the right to take all sorts of liberties, making their presence felt by being loud while sitting at the tables in the sumptuous eateries dressed in full campaign regalia, as the saying goes, but without even taking the precaution of washing their hands or shaving, and after making the obligatory spit balls out of bread crumbs and realising how ridiculous they look, they start to use letter openers or toothpicks to clean their nails, not caring about the repugnance such lack of inhibition occasions ... There one can marvel at the mob which arrives with their suitcases full of parade uniforms and three-cornered hats with ostrich feathers, travelling to the United States or in transit to Europe to represent their respective governments, who are distinguished by their dark skin and a horrid vulgarity ... it doesn't matter if their business is commercial, political, religious, social or diplomatic, as regards their conjugal fidelity and thirst for knowledge, they follow the edifying example set by don Emeterio [he of the visit to the brothel], with the only difference that given the financial standing of the pupil, they carry out their studies with more richly bound works (240-1, my translation).

The graphic description of the excessive satisfaction of bodily impulses toward consumption and sex are positively Rabelaisian and over the top, the writer obviously delighting in the vulgarity, irreverence and sheer carnality of the satirical portraits.

The narrator goes on to ridicule the rusticity and ignorance of other Latinos, too, like the 'inventors who couldn't explain why there were no buyers for a patented project like the fabrication of sandals made with banana tree fibre and return to their homeland screaming that the Yankees were ignorant' (233, my translation); or those who:

because of ignorance about the mechanism of toilet bowl flushing, were always on the point of flooding the building; and others, who alleged that as they were victims of malaria or had a cold, they couldn't use flush toilets for fear that being splashed might make them even sicker, and thus demanded ... that they be provided with receptacles more consonant with what they were used at home (243-4, my translation). 
Clerics are also lampooned and in the most sarcastic fashion:

members of the ecclesiastical fraternity, generally in transit to Rome and without their sacramental clothes, instead of swarming through the doors of temples, sneak quietly and with more eagerness than the most vulgar public into mansions identical to the ones chosen by Peñuela in that memorable night when Lucas Guevara sacrificed his virginity. (233, my translation).

What is significant here is that, while the novel pretends to function as a cautionary moral, it nevertheless overflows such functional limits and is transformed into a uniformly negative image of Latin Americans - for the narrator there is no redemptive dignity or altruism, save for the chaste virgins of paradise lost.

Even the Latin American political radicals who use New York as a base for their activities feel the heat of the narrator's scorn, as Lucas Guevara also provides an occasion to contrast how Díaz-Guerra deals with the condition of exile, in contrast to the likes of José Martí:

Lucas was honoured with invitations to various Hispanic-American clubs, some literary, others political or social, which in general aspired to organize or had organized furious adversaries of yankee imperialism who imagine, perhaps because of some cultural atavism, that it is enough for a citizen of Santa Catalina to frown such that the government in Washington catches its breath, and that availing himself of inflammatory pamphlets, manages to recruit a few dozen tabacco workers or analogous elements so that in the name of the 'Pan American Alliance', the 'Circle of Free Nations' or other such titles, swears to defend the privileges of religion and blood, or even of language, for reasons not hard to figure out (244, my translation).

The reference to Cuban and Puerto Rican political activists is absolutely clear here. What is going on? Let us speculate. The image that comes out of such social satire is wholly pessimistic - there are no counter exceptions, no altruistic political gestures by exiled Latin Americans. Let us also recall that Díaz Guerra was himself somewhat of a radical in Colombia and was ordered to leave Venezuela for this very reason. Somewhere along the way something has occasioned such disillusion, perhaps the perception that political radicals are part of the problem and not the solution in Latin America, or perhaps through the prism of a long residence in the United States his zeal had been tempered. Either way, Díaz Guerra obviously had no compunction about reprising Martí’s use of Coney Island 
to write an exemplary chronicle of mass culture in the novel. ${ }^{6}$ A reading of both Martí's chronicle and the relevant chapter in Lucas Guevara reveals many similarities, especially an abhorrence of mass cultural entertainment, indeed the massification of society in general. Both display a deep ambivalence towards US modernity. As Kanellos and Hernández point out, in Lucas Guevara 'The technological marvels of their "advanced” civilization do away with humanism, dignity and respect. The immigrant is only a beast of burden or "camel" necessary for the physical construction of this technological marvel’ (Kanellos \& Hernández 2001, v-vi, my translation).

Nor do the parallels with Martí end there. In Divergent Modernities (2001), his magisterial study of the cultural politics of Latin America's nineteenth-century intellectual elites, including their attitude towards the cultural modernity of the United States, Julio Ramos contends that, in spite of Martí's sense of alienation, he stayed in New York, not only in order to have a base from which to prosecute his revolutionary activities, but also to be near a functioning 'literary market' (to use Marti's own words, cited in Ramos 2001, 63). Paradoxically, therefore, 'The city, in the very movement that it generated such a 'crisis', an 'alienation', or 'exile', is nevertheless the condition of possibility for the intellectual's autonomy from traditional institutions, an autonomy that was indispensable for the modern intellectual (in contrast to the letrado or 'civil' writer)' (Ramos 2001, 64). No doubt Díaz Guerra also took advantage of such autonomy to refashion himself, but away from that of the activist letrado to that of the detached, ironic literato.

\section{Conclusion}

The historical context for the writing of Lucas Guevara was the onset of capitalist, socioeconomic modernisation driven by the second industrial revolution, in full swing in the West by the end of the nineteenth century and the beginning of the twentieth (1880-

6 Martí's chronicle on Coney Island appeared in a Bogotá newspaper, La Pluma, December 3, 1881 (Ramos 2001, 215). Díaz Guerra would have been 19 years old at the time and given his integration into the lettered culture of Colombian journalism and politics, one imagines he read the chronicle and was suitably impressed. 
1914). The United States was in a more advanced industrial stage than any other country at this time, with the possible exception of Germany, certainly in its major urban centres and in its combination of democratic and religious freedoms. Coupled with a rapidlyexpanding economy and a beneficent immigration policy until the 1920s, it became attractive to immigrants and exiles alike. ${ }^{7}$ Lucas Guevara can be regarded, then, as Díaz Guerra's aesthetic impulse to recover from, compensate for, or simply come to terms with, the shock of secular, urban modernity and the condition of exile/immigration. Embedded within the novel is thus the accumulated experience and observation of a Latino flâneur reflecting on urban massification and the impact of technological change on the quality of individual experience. Historical studies and memoirs like Harry Roskolenko's moving portrait of his Jewish childhood on the Lower East Side in the early decades of the twentieth century corroborate the ambience sketched in Díaz Guerra’s novel. Roskolenko’s description of the Jewish exodus from Eastern Europe to New York doubles for most immigrants:

All of them were seeking the Goldeneh Medina - the Golden Land - within a few square miles of the Lower East Side. But what they found became New York's triumphs and tragedies of reckless architecture, sudden slums, terrible factories - and the high-rises that still signify rush, hurry, ghetto gutting, and today’s city living and dying from every pore (Roskolenko 1971, 5).

That Díaz Guerra has Lucas Guevara throw himself off the Brooklyn Bridge, that symbol of modernity in the novel's finale, echoes the difficult relationship with modernity that many Latin Americans would henceforth have, whether in the United States or at home. Equally significant, of course, is that Díaz Guerra himself eventually managed to accommodate to the circumstances, as many exiles and immigrants eventually do.

Along with this socio-economic modernisation came cultural change, not only in the arts, but in social behaviour, especially in relation to changing sexual mores: secular humanism and the discovery of sensuality, eroticism and furtive love in the civil life of the mushrooming capital cities. The period when Díaz Guerra arrives in New York also coincided with the boom of modernismo, the first authentically literary-cultural

7 'In fifteen years, between 1899 and 1914, more than one million and a half immigrants came to Ellis Island - and most remained in New York’ (Roskolenko 1971, 18). 
movement to be generated in Latin America and subsequently to be transplanted to Spain. Its new aesthetic left Díaz Guerra’s poetry writing untouched, he being still mired in style and content in a sentimental romanticism. But neither was he accepting of modernismo's libertine sexual politics, which everywhere was invading souls, especially among liberals. Thus the accumulated images of eroticism that are expressed through the narrative voice in Lucas Guevara are consistent with the commonplace perception on the part of Latin Americans, especially immigrant writers, about the predatory and emasculating potential of US women vis-à-vis Latino males. There is therefore a conventional (in terms of immigrant literature) movement of attraction/rejection of modernity and its sensuality: their appeal, but also the anxiety they unleash.

This tension between attraction and repulsion is nicely captured in a most revealing aside towards the end of the novel, when the narrator in apologetic mode attempts to explain why Guevara cannot resist temptations that lead to disaster:

it would not be entirely justified to place the full weight of guilt upon the misfortunate lad [Guevara], above all if one keeps in mind that in the overpowering milieu in which he was spinning, one needs nerves of steel to withstand the trial by fire of the myriad temptations that lay siege to mortals, and like the nymphs in Faust's dream, there is no corner where they don't entice with their gratifying sensations (Díaz Guerra 2001, 299, my translation).

The problem should be obvious: even the narrator finds it hard to resist - all Latinos are doomed to succumb to the corrupting influence of secular modernity.

Aside from its uniqueness as the first known novel of Latin American immigration to the United States written in Spanish, Lucas Guevara has sociological value because it is a not only a witness to the metropolis of New York in one of its most expansive phases, but also to an incipient women's liberation from traditional sexual roles, which highlights the way secular modernity unleashes both desire and social mobility. Furthermore, it draws attention, in almost laboratory fashion, to the assault on Latino male subjectivity, at least that of an elite Creole exile-cum-immigrant. Male exiles found themselves living in a society which protected their freedoms of expression and assembly, but which embodied values alien to supposedly more traditional Latino conceptions of family values, 
including filial piety, female chastity, and masculinist codes of honour. Though it is always risky to equate narrative point of view with that of the author, implied or otherwise, nevertheless the accumulative logic of Lucas Guevara seems to strongly suggest that with the passing years, Díaz Guerra himself was able to distance himself from both the host culture and his own, while acknowledging the positive in both: the practical knowledge and technological achievements of the United States (and there are certainly positive references to the country's achievements and freedoms); and the 'more authentic' values of Latinos, though as we have seen, these are no where to be found in the New York of Lucas Guevara. The composite perspective or world view that seems to issue from the narrative voice, then, is that of suitably chastened and detached, cultured intellectual who looks upon life in general in an ironic and mocking way. Furthermore, the image of the narrator does indeed seem to be an instance of a 'mordacious and moralizing satire ... [which] reinforces the rejection of Anglo-American culture and the conservation of the Hispanic-American identity of the immigrants' (xv, my translation), as Kanellos and Hernández claim.

The life of the Lower East Side in the novel, therefore, parallels a real-life both then and now in New York and the United States in general: the desire to assimilate immigrants to the dominant cultural ethos and the immigrant's resistance to, or difficult negotiation of, such homogenising tendencies. The literature of immigration of this period stands out for its thematization at times satirical and critical of the problems encountered by the minority immigrant (especially Southern Italians, Eastern European Jews, Chinese and Mexicans), including labour exploitation and racial and cultural discrimination. ${ }^{8}$ In face of such hostility, native language and culture and conservative values are doubly asserted and confirmed. As Kanellos points out, historically one of the functions of Latin American literature and periodicals in the US was to 'protect Hispanic language, culture and values' (Kanellos 2000, 69) even if those values were masculinist:

8 Alan Kraut: 'The late nineteenth century brought to the United States millions of Catholics and Jews and darker-skinned people, duskier complexions, many of them in much greater levels of poverty than those who had come at an earlier time. The result is that there was a tremendous belief on the part of American nativists that these newcomers were of inferior stock, that they simply were not as good as the western and northern Europeans that had come at an earlier time ...' http://www.pbs.org/fmc/interviews/kraut.htm 
These authors assign responsibility for preserving Hispanic language and customs and thus protecting identity to Latina women: thus they punish them severely when they adopt the liberal customs of the Anglo-Saxons or dare to behave like 'bitches"' (Kanellos 2002, xxxv, my translation).

Modernity unlocks what has always been an uneasy and fragile divide between the sexual self and the spiritual self, a divide that seems difficult to bridge within the precepts of orthodox religions. This unresolved tension is often displaced onto convenient scapegoats: licentious women, other cultures, or simply modernity. When these tensions are combined with the condition of exile or immigration, they can become volatile, or simply lead to welcome change. Díaz Guerra seems to be one exile who largely made his peace with his adopted country, if not with modern sexuality, though such a transformation was obviously made possible by his privileged starting point - the social and cultural capital accumulated though his patrician upbringing.

Thus, even though Lucas Guevara touches on exilic themes of loss, isolation, incarceration, and exploitation as its protagonist descends into social and moral ruin, Díaz Guerra’s ethnic and racist profiling of Jews, Chinese, dark-skinned people and AngloSaxons and his position as a privileged Creole elite, distances him (and his fictional, middle-class student protagonist) from the more typical trajectory of the hundreds of thousands of underclass Latino immigrants, exiles, and political refugees who flooded into the US over the course of the twentieth century. Though he arrived in the US with probably very little economic capital, Díaz Guerra nevertheless possessed enough class status to obtain work as a correspondent for several Spanish American newspapers, to secure a senior sales position with an international pharmaceutical company, to even act as Director of the Colombian Information Office in New York, evidence that he had largely resolved his differences with the Colombian Conservative government and had been transformed from exile to confirmed immigrant. He belongs, then, to a particular fraction of a displaced, educated Latino Creole elite, and one moreover with a decidedly conservative cast of mind, nostalgic for the loss of status and legislative hegemony that attached to them within the class and gendered social hierarchies in their home countries, 
a loss that becomes sublimated into the puritanical and overweening moralism of Catholic conservatism.

\section{Reference List}

Díaz Guerra, Alirio (1933), Diez años en Venezuela, Editorial Élite, Caracas.

_ (2001) Lucas Guevara, Intro.N. Kanellos \& I. Hernández, Arte Público Press, Houston.

Erenberg, Lewis (1981), Stepping Out: New York Nightlife and the Transformation of American Culture, 1890-1930, University of Chicago Press, Chicago.

Kanellos, Nicolás, (unpublished manuscript) 'La expresión cultural de los inmigrantes mexicanos en los Estados Unidos, desde el Porfiriato hasta la Depresión’.

_ (2002), 'Panorama de la literatura hispana de los Estados Unidos’ en Kanellos, Nicolás et al. (2002) En otra voz: Antología de la literatura hispana de los estados Unidos, Arte Publico Press, Houston.

— \& Martell, Helvetia (2000), Hispanic Periodicals in the United States: Origins to 1960. Houston: Arte Público Press, Houston.

—_ \& Hernández, Imra L (2001), 'Introducción. Lucas Guevara: La primera novela de inmigración hispana a los Estados Unidos’, en Díaz Guerra, Alirio Lucas Guevara, Arte Público Press, Houston.

— et al. (2002), En otra voz: Antología de la literatura hispana de los estados Unidos, Arte Público Press, Houston.

Kraut, Alan, Interview, available at http://www.pbs.org/fmc/interviews/kraut.htm. Accessed November 3, 2004.

Maffi, Mario (1995), Gateway to the Promised Land: Ethnic Cultures in New York's Lower East Side, New York University Press, New York \& London.

Ramos, Julio (2001), Divergent Modernities: Culture and Politics in Nineteenth-Century Latin America, trans. By John D. Blanco, Duke University Press,Durham \& London.

Roskolenko, Harry (1971), The Time That Was Then. The Lower East Side: 1900-1913An Intimate Chronicle, Dial Press, New York.

Simmel, Georg ([1903] 2002), 'The Metropolis and Mental Life’ in Gary Bridge \& Sophie Watson (eds), The Blackwell City Reader, Blackwell, London.

Zorilla, José (1844), Don Juan Tenorio (play). 